\title{
PERAN UKURAN PERUSAHAAN DAN PERTUMBUHAN PENJUALAN DALAM MEMODERASI PENGARUH STRUKTUR MODAL TERHADAP PROFITABILITAS
}

\author{
Ni Luh Made Wiwiek Oktapiani ${ }^{1}$ \\ I Gusti Bagus Wiksuana ${ }^{2}$ \\ ${ }^{1,2}$ Fakultas Ekonomi dan Bisnis Universitas Udayana, Bali, Indonesia \\ email: wiwiekoktapiani@yahoo.co.id
}

\begin{abstract}
ABSTRAK
Penelitian ini bertujuan untuk mengetahui pengaruh struktur modal terhadap profitabilitas serta mengetahui kemampuan ukuran perusahaan dan pertumbuhan penjualan dalam memoderasi pengaruh struktur modal terhadap profitabilitas. Penelitian ini menggunakan pendekatan kuantitatif bersifat asosiatif. Penelitian ini berlokasi pada perusahaan sektor pertambangan di Bursa Efek Indonesia periode 2012 - 2016 dengan jumlah populasi 42 perusahaan dan sampel yang digunakan berjumlah 25 perusahaan. Teknik analisis pada penelitian ini adalah moderate regression analysis (MRA). Berdasarkan pengujian asumsi klasik menunjukkan hasil bahwa model regresi yang digunakan sudah tepat. Hasil penelitian dengan menggunakan analisis regresi moderasi menunjukkan bahwa terdapat pengaruh positif antara struktur modal terhadap profitabilitas. Ukuran perusahaan mampu memoderasi pengaruh struktur modal terhadap profitabilitas tetapi pertumbuhan penjualan tidak mampu memoderasi pengaruh struktur modal terhadap profitabilitas.
\end{abstract}

Kata kunci: struktur modal, profitabilitas, ukuran perusahaan, pertumbuhan penjualan.

\begin{abstract}
This study aims to determine the effect of capital structure on profitability and to know the ability of firm size and sales growth in moderating the influence of capital structure on profitability. This study uses quantitative approach is associative. This research is located at mining company in Indonesia Stock Exchange period 2012 - 2016 with population of 42 companies and samples used amounted to 25 companies. The analysis technique in this research is moderate regression analysis (MRA). Based on the classical assumption test shows the result that the regression model used is correct. Result of research by using regression analysis of moderation indicate that there is positive influence between capital structure to profitability. Firm size is able to moderate the effect of capital structure on profitability but sales growth is not able to moderate the effect of capital structure on profitability.

Keywords: capital structure, profitability, firm size, sales growth.
\end{abstract}




\section{PENDAHULUAN}

Dunia bisnis saat ini telah jauh lebih komplek dibandingkan sebelumnya. Hal ini menunjukkan adanya perubahan yang dinamis dalam dunia bisnis, namun hanya sedikit pelaku bisnis yang menyiapkan diri dalam menghadapi perubahan lingkungan yang cepat dan dinamis tersebut (Umar, 2003:5). Perubahan lingkungan yang terjadi menimbulkan adanya persaingan global yang menyebabkan sebuah perusahaan membutuhkan strategi untuk dapat mempertahankan kelangsungan hidup secara individual maupun dalam korporasi untuk dapat meningkatkan profitabilitasnya (Purwitasari dan Septiani, 2013). Semakin besar kegiatan ekspansi perusahaan menyebabkan perusahaan juga akan mengalami peningkatan kebutuhan pendanaan (Rosyadah dkk. 2013). Hal ini menyebabkan banyak perusahaan yang mengalami kesulitan dalam pendanaan (Masfufah, 2016).

Proporsi pendanaan perusahaan adalah penggabungan antara dana jangka jangka panjang dan jangka pendek. Sumber dana jangka pendek berasal dari pendanaan jangka pendek atau utang lancar seperti utang dagang, utang bank, commercial paper, factoring dan lain - lain, sedangkan dana jangka panjang yang digunakan untuk investasi atau peningkatan kapasitas produksi diperoleh dari sumber pendanaan jangka panjang, misalnya obligasi dan saham (Rosyadah dkk. 2013).

Pratheepkanth (2011), Khan et al. (2013) dan Kumar and Babu (2016) menyebutkan bahwa struktur modal mengacu pada pilihan yang berbeda antara penggunaan utang dan ekuitas yang digunakan dalam pembiayaan aset perusahaan. Niresh (2012) dan Pattweekongka and Napompech (2014) menyatakan bahwa 
Ni Luh Made Wiwiek Oktapiani, Peran Ukuran Perusahaan ...

keputusan struktur modal penting bagi perusahaan karena keputusan ini secara langsung mampu mempengaruhi profitabilitas perusahaan. Pernyataan tersebut juga dinyatakan oleh Rostami and Akbarpur (2012) yang menyatakan bahwa struktur modal dari suatu perusahaan dapat mempengaruhi kinerja perusahaan secara keseluruhan. Kinerja perusahaan terbagi menjadi dua jenis yaitu kinerja keuangan dan kinerja non-keuangan. Kinerja keuangan adalah suatu alat ukur yang digunakan untuk mengetahui kemampuan perusahaan dalam menghasilkan laba (Tjahjono, 2016). Anwar (2009) dan Fachrudin (2011) menyebutkan bahwa kinerja keuangan perusahaan sangat jelas terlihat pada laba yang dihasilkan dari keseluruhan operasi perusahaan yang mencerminkan keadaan keuangan perusahaan.

Profitabilitas merupakan kemampuan perusahaan dalam memperoleh laba berkaitan dengan modal sendiri, total aktiva, maupun penjualan (Sartono, 2012:122). Sudaryo dan Pratiwi (2016) menyatakan perusahaan harus memperhatikan profitabilitasnya, karena untuk menjaga kelangsungan kehidupan perusahaan harus berada dalam keadaan untung atau laba. Berbagai faktor yang dapat mempengaruhi penurunan dan peningkatan laba perusahaan diantaranya debt to euity ratio (DER), total asset turnover (TATO), current ratio (CR), debt ratio (DR), ukuran perusahaa, dan pertumbuhan penjualan (Barus dan Leliani, 2013). Profitabilitas perusahaan dapat diukur dengan menggunakan rasio return on asets (Wiagustini, 2014). Semakin tinggi presentase return on assets (ROA) menunjukkan semakin baiknya kinerja perusahaan karena return yang dihasilkan semakin besar untuk menjalankan operasi perusahaan (Yulia, 2013). 
Hubungan struktur modal dengan profitabilitas dijelaskan melalui dua teori yaitu pecking order theory dan trade of theory. Pecking order theory menjelaskan bahwa semakin tinggi tingkat penggunaan utang perusahaan mengindikasikan kemampuan perusahaan untuk memperoleh laba akan semakin menurun karena umumnya perusahaan akan lebih memilih menggunakan pendanaan internal daripada pendanaan eksternal (Nurcahyani, 2014). Penjelasan berbeda dijelaskan pada trade of theory yang menyatakan bahwa penggunaan utang sampai tingkat tertentu akan bermanfaat pada penghematan pajak (tax shields) yang dilakukan perusahaan (Dewi dan Wirajaya, 2013). Menurut Nurcahyani (2014) pengukuran solvabilitas perusahaan dapat diukur dengan debt to total assets ratio (DAR). Semakin besar presentase debt to total ratio, menunjukkan jumlah modal pinjaman yang digunakan oleh perusahaan semakin besar untuk pembiayaan aset perusahaan. Pentingnya keputusan struktur modal juga harus diperhatikan oleh perusahaan sektor pertambangan untuk menjaga profitabilitasnya. Perusahaaan sektor pertambangan merupakan salah satu perusahaan yang tergolong dalam perusahaan sektor utama penghasil bahan baku. Apabila kegiatan operasi perusahaan sektor utama melemah maka akan berdampak pula pada perusahaan sektor lainnya. Maka dari itu, perusahaan sektor pertambangan sebagai perusahaan sektor utama penting untuk memiliki profitabilitas yang maksimal untuk menjaga kelangsungan kehidupan jangka panjang perusahaan dalam persaingan global saat ini.

Beberapa penelitian sebelumnya untuk menguji pengaruh struktur modal terhadap profitabilitas perusahaan pernah dilakukan seperti penelitian yang 
Ni Luh Made Wiwiek Oktapiani, Peran Ukuran Perusahaan ...

dilakukan oleh Stein (2012), Chechet and Olayiwola (2014), Hasan et al. (2014), dan Boutilda dan Gandakusuma (2014) yang menemukan bahwa terdapat pengaruh negatif signifikan antara rasio struktur modal terhadap tingkat profitabilitas perusahaan. Hasil penelitian lain oleh Nawaz et al. (2011), Binangkit dan Raharjo (2014), dan Marusya dan Magantar (2016), menunjukkan bahwa terdapat pengaruh positif signifikan struktur modal dengan profitabilitas. Penelitian lainnya oleh Niresh (2012) dan Shaputri dan Wibowo (2016) menyatakan bahwa struktur modal memiliki hubungan positif terhadap profitabilitas namun tidak signifikan. Berdasarkan adanya perbedaan hasil temuan mengenai pengaruh struktur modal terhadap profitabilitas tersebut maka terdapat celah penggunaan variabel moderasi dalam penelitian ini.

Dalam penelitian ini menggunakan variabel ukuran perusahaan dan pertumbuhan penjualan untuk memoderasi pengaruh struktur modal terhadap profitabilitas. Semakin besar ukuran perusahaan dan pertumbuhan penjualan menyebabkan persentase perolehan profitabilitas semakin meningkat, namun disisi lain beberapa penelitian menemukan bahwa ukuran perusahaan dan pertumbuhan penjualan memiliki hubungan berlawanan arah dengan profitabilitas bahkan tidak memiliki pengaruh signifikan. Penelitian ini bertujuan untuk mengetahui pengaruh struktur modal terhadap profitabilitas serta kemampuan ukuran perusahaan dan pertumbuhan penjualan dalam memoderasi pengaruh struktur modal terhadap profitabilitas.

Thippayana (2014) dan Sudaryo dan Pratiwi (2016) menyatakan bahwa pembentukan struktur modal penting diperhatikan oleh perusahaan khususnya 
dalam hal pendanaan perusahaan. Struktur modal merupakan keputusan pendanaan yang dilakukan oleh manajer keuangan yang intinya memilih apakah akan mendanai operasi perusahaan dengan menggunakan utang ataupun ekuitas (Marusya dan Magantar, 2016). Pecking order theory dan trade off theory merupakan dua teori yang dapat mempengaruhi keputusan struktur modal. Trade off theory menyatakan bahwa penggunaan utang perusahaan akan sampai pada tingkat tambahan utang yang bermanfaat pada penghematan pajak (tax shields) sama dengan biaya kesulitan keuangan (Dewi dan Wirajaya, 2013). Menurut pecking order theory pendanaan perusahaan dimulai dari menggunakan laba ditahan, lalu utang kemudian modal eksternal (Husnan dan Pudjiastuti, 2006:276). Ukuran perusahaan adalah cerminan kondisi keuangan perusahaan pada suatu periode (Masfufah, 2016). Skala atau ukuran perusahaan dinyatakan memiliki dua kategori yaitu perusahaan skala besar dan skala kecil. Ukuran perusahaan yang berbeda menyebabkan adanya perbedaan risiko usaha yang dihadapi perusahaan (Lim, 2012). Dalam kegiatan pendanaan biasanya perusahaan ukuran kecil memiliki kapasitas kurang dana sedangkan perusahaan-perusahaan besar memiliki kapasitas lebih tinggi untuk mengumpulkan dana (Yadav, 2014). Pertumbuhan penjualan mengindikasikan terjadinya peningkatan pangsa pasar yang mengakibatkan adanya peningkatan profitabilitas perusahaan (Putra dan Badjra, 2015).

Pecking order theory menyebutkan bahwa tingkat penggunaan utang perusahaan yang semakin tinggi mengindikasikan kemampuan untuk memperoleh laba akan semakin menurun karena umumnya perusahaan akan lebih memilih 
Ni Luh Made Wiwiek Oktapiani, Peran Ukuran Perusahaan ...

menggunakan pendanaan internal daripada pendanaan eksternal (Nurcahyani, 2014). Hal tersebut mengindikasikan bahwa rasio struktur modal yang semakin tinggi menyebabkan risiko keuangan yang dihadapi dalam pencapaian profitabilitas perusahaan juga semakin besar. Hasil temuan yang mendukung pernyataan tersebut adalah Seikh and Wang (2013), Khan et al. (2013), Purwitasari dan Septiani (2013), Nurcahyani (2014), Marusya dan Magantar (2016), Rosyadah dkk. (2013), Hasan et al. (2014), Kipesha and Moshi (2014), Twairesh (2014) dan Mumtaz et al. (2013) yang menemukan struktur modal berpengaruh negatif signifikan terhadap profitabilitas.

$\mathrm{H}_{1}$ : Struktur modal berpengaruh negatif signifikan terhadap profitabilitas

Ukuran perusahaan yang semakin besar menunjukkan bahwa peluang perusahaan untuk memperoleh keuntungan dari hasil operasinya juga akan semakin besar, hal ini menunjukkan bahwa perusahaan sedang mengalami perkembangan dan pertumbuhan yang baik (Rudangga dan Sudiarta, 2016). Khan et al. (2013) dan Sheikh and Wang (2013) yang menggunakan ukuran perusahaan sebagai variabel kontrol guna mengetahui pengaruh struktur modal terhadap kinerja keuangan perusahaan menemukan bahwa ukuran perusahaan memiliki pengaruh positif signifikan terhadap kinerja keuangan perusahaan yang diukur dengan return on asset (ROA). Meidiyustiani (2016), Sunarto dan Budi (2009) serta Purba dan Yadnya (2015) juga menemukan ukuran perusahaan memiliki pengaruh positif terhadap profitabilitas.

$\mathrm{H}_{2}$ : Ukuran perusahaan secara signifikan mampu memoderasi pengaruh struktur modal terhadap profitabilitas. 
Pertumbuhan penjualan yang semakin tinggi menyebabkan keuntungan yang diperoleh juga semakin besar. Pihak internal maupun eksternal perusahaan sangat mengharapkan pertumbuhan perusahaan tersebut karena pertumbuhan yang terjadi mengindikasikan adanya perkembangan sebuah perusahaan (Dramawan, 2015). Pernyataan tersebut didukung oleh penelitian yang dilakukan Sheikh and Wang (2013) untuk meneliti pengaruh antara struktur modal terhadap kinerja keuangan yang diukur dengan return on assets (ROA) dengan menggunakan pertumbuhan penjualan sebagai variabel kontrol menemukan bahwa pertumbuhan penjualan memiliki pengaruh posistif signifikan terhadap Return on Assets (ROA). Fahrana dkk. (2016), Purwitasari dan Septiani (2013) dan Boutilda dan Gandakusuma (2014) menyatakan pertumbuhan penjualan memiliki pengaruh positif signifikan terhadap profitabilitas.

$\mathrm{H}_{3}$ : Pertumbuhan penjualan secara signifikan mampu memoderasi pengaruh struktur modal terhadap profitabilitas.

Untuk mempermudah pemahaman mengenai penelitian yang dilakukan, disajikan kerangka konseptual sebagai berikut.

\section{Gambar 1. Kerangka Konseptual}

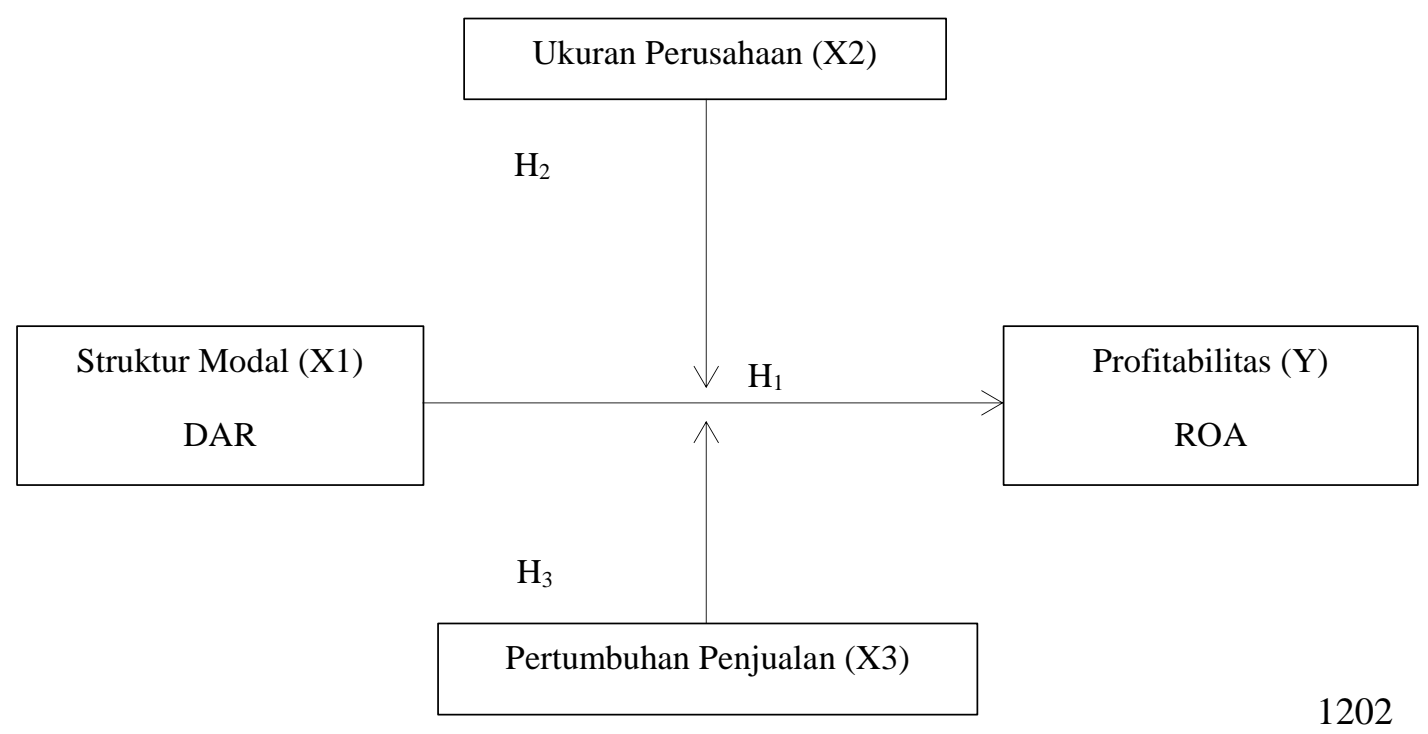


Ni Luh Made Wiwiek Oktapiani, Peran Ukuran Perusahaan ...

\section{METODE PENELITIAN}

Penelitian ini menggunakan pendekatan kuantitatif bersifat asosiatif. Jenis data kuantitatif dengan sumber data sekunder dari laporan keuangan tahunan perusahaan sektor pertambangan selama periode 2012 - 2016 yang dipublikasikan pada $\underline{w w w . i d x . c o . i d ~ d i g u n a k a n ~ s e b a g a i ~ d a t a ~ p e n e l i t i a n . ~ P e n g u m p u l a n ~ d a t a ~ p a d a ~}$ penelitian ini menggunakan teknik observasi bersifat nonpartisipan. Teknik analisis yang digunakan yaitu Moderated Regression Analysis (MRA) untuk menguji peranan variabel moderasi dalam mempengaruhi variabel bebas dan variabel terikat.

Penelitian ini berlokasi pada perusahaan sektor pertambangan di Bursa Efek Indonesia. Pemilihan perusahaan sektor pertambangan sebagai lokasi penelitian karena sektor pertambangan termasuk dalam industri penghasil bahan baku yang memerlukan pendanaan yang cukup besar dalam kegiatan operasionalnya sehingga penting bagi perusahaan untuk mengelola struktur modalnya agar tidak mengganggu aktivitas operasional perusahaan yang nantinya akan berdampak pada perolehan profitabilitas.

Pengumpulan sampel dilakukan dengan pendekatan non - probability sampling dengan teknik purposive sampling yang menggunakan syarat pemilihan sampel yaitu perusahaan sektor pertambangan yang mempublikasikan laporan keuangan tahunan secara lengkap pada 2012 - 2016. Dari populasi sebanyak 42 perusahaan sektor pertambangan di Bursa Efek Indonesia hanya 25 perusahaan yang memenuhi persyaratan tersebut yang digunakan sebagai sampel penelitian. 
Penelitian ini menggunakan tiga jenis variabel yaitu ukuran perusahaan sebagai variabel terikat, struktur modal sebagai variabel bebas dan variabel moderasi yakni ukuran perusahaan dan pertumbuhan penjualan. Profitabilitas merupakan keuntungan perusahaan saat melakukan kegiatan operasional pada perusahaan sektor pertambangan di Bursa Efek Indonesia (BEI) periode 2012-2016 yang diukur menggunakan pendekatan return on assets (ROA). Satuan pengukuran return on assets (ROA) dalam persentase yaitu sebagai berikut.

$$
\mathrm{ROA}=\frac{\text { Laba bersih }}{\text { Total aktiva }} \times 100 \%
$$

Struktur modal adalah keputusan pendanaan untuk mendanai operasional perusahaan baik menggunakan utang ataupun ekuitas pada perusahaan sektor pertambangan di Bursa Efek Indonesia (BEI) periode 2012-2016 yang diukur menggunakan pendekatan debt to total assets ratio (DAR). Debt to total assets ratio (DAR) dirumuskan melalui rasio sebagai berikut.

$$
\mathrm{DAR}=\frac{\text { total utang }}{\text { total aset }} \times 100 \%
$$

Ukuran perusahaan adalah gambaran kemampuan finansial perusahaan sektor pertambangan di Bursa Efek Indonesia (BEI) periode 2012-2016. Pengukuran ukuran perusahaan dinyatakan dalam satuan rupiah dirumuskan sebagai berikut.

$$
\text { Ukuran perusahaan }=\text { logaritma natural dari total aset. }
$$

Pertumbuhan penjualan mencerminkan ukuran mengenai kondisi kestabilan keuangan perusahaan sektor pertambangan di Bursa Efek Indonesia (BEI). Satuan pengukuran rasio ini adalah sebagai berikut.

$$
\text { Pertumbuhan penjualan }=\frac{\text { penjualan } \mathrm{t} 1-\text { penjualan } \mathrm{t} 0}{\text { penjualan } \mathrm{t} 0} X 100 \%
$$


Ni Luh Made Wiwiek Oktapiani, Peran Ukuran Perusahaan ...

Penelitian ini menggunakan model persamaan regresi sebagai berikut:

$$
Y=a+\beta 1 X 1+\beta 2 X 2+\beta 3 X 3+\beta 4 X 1 X 2+\beta 5 X 1 X 3+e
$$

Keterangan :

Y : profitabilitas (ROA)

a : konstanta

$\beta 1, \beta 2, \beta 3, \beta 4, \beta 5$ : koefisien regresi

$\mathrm{X} 1$ : struktur modal (DAR)

X2 : ukuran perusahaan

$\mathrm{X} 3$ : pertumbuhan penjualan

X1X2 : interaksi antara struktur modal dengan ukuran perusahaan

X1X3 : interaksi antara struktur modal dengan pertumbuhan penjualan

e : Error (I)

\section{HASIL DAN PEMBAHASAN}

Analisis statistik deskriptif menunjukkan mengenai data variabel penelitian yang terlihat dari jumlah pengamatan, nilai rata - rata (mean), sum, standar deviasi, range, nilai minimum, dan nilai maksimum. Tabel 1 dibawah ini menampilkan statistik deskripsi variabel yang telah diuji menggunakan program SPSS versi 20.

Tabel 1 mengindikasikan bahwa sampel yang digunakan sebanyak 125 data yaitu 25 perusahaan dan 5 tahun periode penelitian. Berdasarkan analisis statistik deskriptif pada Tabel 1 profitabilitas disimbolkan dengan Y yang diproksikan dengan Return on Asset (ROA) menunjukkan nilai rata-rata profitabilitas 2,1490 persen dan standar deviasi sebesar 13,08693. Nilai terendah (minimun) dari 
profitabilitas (Y) adalah -72,13 persen sedangkan nilai tertinggi (maksimum) dari profitabilitas (Y) adalah 29,00 persen. Nilai range sebesar 101,13 persen menunjukkan selisih antara nilai maksimum dan nilai minimum profitabilitas. Nilai sum sebesar 268,62 persen menunjukkan total profitabilitas.

Tabel 1.

Statistik Deskriptif

\begin{tabular}{lcrrrrrr}
\hline & N & \multicolumn{1}{c}{ Range } & Minimum & Maximum & \multicolumn{1}{c}{ Sum } & \multicolumn{1}{c}{ Mean } & Std. Deviation \\
\hline $\mathrm{Y}$ & 125 & 101.13 & -72.13 & 29.00 & 268.62 & 2.1490 & 13.08693 \\
$\mathrm{X} 1$ & 125 & 182.10 & 7.67 & 189.77 & 6590.57 & 52.7246 & 22.55916 \\
$\mathrm{X} 2$ & 125 & 8.35 & 9.91 & 18.26 & 1875.93 & 15.0074 & 1.67436 \\
$\mathrm{X} 3$ & 125 & 582.14 & -43.43 & 538.71 & 3891.39 & 31.1311 & 73.57624 \\
$\mathrm{X} 1 \mathrm{X} 2$ & 125 & 3246.86 & 76.01 & 3322.87 & 99777.78 & 798.2223 & 379.65741 \\
$\mathrm{X} 1 \mathrm{X} 3$ & 125 & 29498.74 & -3602.95 & 25895.79 & 178025.73 & 1424.2058 & 3365.55898 \\
\hline Valid N & 125 & & & & & & \\
(listwise) & & & & & & \\
Sumber: data diolah, 2017 &
\end{tabular}

Berdasarkan Tabel 1 struktur modal disimbolkan dengan X1 yang diproksikan dengan debt to total asset rasio (DAR) memiliki nilai rata-rata (mean) struktur modal 52,7246 persen dengan standar deviasi sebesar 22,55916. Nilai terendah (minimun) dari struktur modal (X1) adalah 7,67 persen, sedangkan nilai tertinggi (maksimum) dari struktur modal (X1) adalah 189,77 persen. Nilai range sebesar 182,10 persen menunjukkan selisih antara nilai maksimum dan nilai minimum. Nilai sum sebesar 6590,57 persen menunjukkan total struktur modal.

Dalam penelitian ini ukuran perusahaan disimbolkan dengan X2. Berdasarkan Tabel 1 rata-rata ukuran perusahaan sebesar 15,0074 rupiah dan standar deviasi sebesar 1,67436. Nilai terendah (minimun) dari ukuran perusahaan (X2) adalah 9,91 rupiah, sedangkan nilai tertinggi (maksimum) dari ukuran perusahaan (X2) adalah 18,26 rupiah. Nilai range sebesar 8,35 rupiah menunjukkan 
Ni Luh Made Wiwiek Oktapiani, Peran Ukuran Perusahaan ...

selisih antara nilai maksimum dan nilai minimum. Nilai sum sebesar 1875,93 rupiah.

Dalam penelitian ini X1X2 merupakan interaksi variabel moderasi ukuran perusahaan terhadap pengaruh antara struktur modal dengan profitabilitas. Berdasarkan analisis statistik deskriptif yang ditunjukkan pada Tabel 1 menunjukkan nilai rata-rata (mean) interaksi struktur modal dengan ukuran perusahaan sebesar 798,2223 dengan standar deviasi sebesar 379,65741. Nilai terendah (minimun) dari inteaksi struktur modal dengan ukuran perusahaan adalah 76,01, sedangkan nilai tertinggi (maksimum) dari interaksi struktur modal dengan ukuran perusahaan adalah 3322,87 . Nilai range sebesar 3246,86 menunjukkan selisih antara nilai interaksi maksimum dan nilai interaksi minimum. Nilai sum sebesar 99777,78 menunjukkan total interaksi struktur modal dengan ukuran perusahaan terhadap profitabilitas.

Dalam penelitian ini pertumbuhan penjualan disimbolkan dengan $\mathrm{X}$ 3 Berdasarkan analisis statistik deskriptif yang ditunjukkan pada Tabel 1 menunjukkan nilai rata-rata (mean) pertumbuhan penjualan 31,1311 persen dengan standar deviasi sebesar 73,57624. Nilai terendah (minimun) dari pertumbuhan penjualan (X3) adalah -43,43 persen, sedangkan nilai tertinggi (maksimum) dari pertumbuhan penjualan (X3) adalah 538,71 persen. Nilai range sebesar 582,14 persen menunjukkan selisih antara nilai maksimum dan nilai minimum pertumubuhan penjualan. Nilai sum sebesar 3891,39 persen menunjukkan total pertumbuhan penjualan perusahaan. 
Pada penelitian ini X1X3 merupakan interaksi variabel moderasi antara pertumbuhan penjualan terhadap pengaruh antara struktur modal dengan profitabilitas. Nilai rata-rata (mean) interaksi struktur modal dengan pertumbuhan penjualan sebesar 1424,2058 dengan standar deviasi sebesar 3365,55898. Nilai terendah (minimun) dari inteaksi struktur modal dengan pertumbuhan penjualan adalah -3602,95 sedangkan nilai tertinggi (maksimum) dari interaksi struktur modal dengan pertumbuhan penjualan adalah 25895,79.

Pengujian asumsi klasik dilakukan untuk mengetahui kelayakan model regresi berdasarkan asumsi metode kuadrat terkecil yang terdiri dari BLUE (Best, Linear, Unbias Estimator). pengujian asumsi klasik terdiri atas empat pengujian yaitu uji normalitas, multikolinearitas, heteroskedastisitas dan autokorelasi.

Tabel 2.

Hasil Uji Normalitas

\begin{tabular}{lr}
\hline \multicolumn{2}{c}{ One-Sample Kolmogorov-Smirnov Test } \\
& Unstandardized Residual \\
\hline $\mathrm{N}$ & 125 \\
Kolmogorov-Smirnov Z & 1.896 \\
Asymp. Sig. (2-tailed) & .151 \\
\hline Sumber: data diolah, 2017
\end{tabular}

Berdasarkan Tabel 2. tersebut menunjukkan nilai koefisien Asymp. Sig. (2tailed) sebesar 0,151 lebih besar dari taraf nyata yang digunakan $a=0,05(0,151>$ 0,05). Hasil tersebut menunjukkan bahwa data yang digunakan dalam model regresi berdistribusi normal.

Berdasarkan Tabel 3 tersebut terlihat bahwa nilai koefisien tolerance dari setiap variabel yang digunakan lebih besar sama dengan 0,10 serta nilai varian 
Ni Luh Made Wiwiek Oktapiani, Peran Ukuran Perusahaan ...

inflatation factor (VIF) lebih kecil sama dengan 10. Maka dapat disimpulkan bahwa tidak terjadi gejala multikoleniaritas antar variabel dalam model.

Tabel 3.

Hasil Uji Multikoleniaritas

\begin{tabular}{lcc}
\hline Variabel & Tolerance & VIF \\
\hline $\mathrm{X} 1$ & .127 & 8.639 \\
$\mathrm{X} 2$ & .187 & 5.335 \\
$\mathrm{X} 3$ & .101 & 9.871 \\
$\mathrm{X} 1 \mathrm{X} 2$ & .113 & 8.240 \\
$\mathrm{X} 1 \mathrm{X} 3$ & .101 & 9.857 \\
\hline Sumber: data diolah, 2017 & &
\end{tabular}

Tabel 4.

Hasil Uji Heteroskedastisitas

\begin{tabular}{ll}
\hline \multicolumn{1}{c}{ Variabel } & Sig. \\
\hline $\mathrm{X} 1$ & .127 \\
$\mathrm{X} 2$ & .071 \\
$\mathrm{X} 3$ & .329 \\
$\mathrm{X} 1 \mathrm{X} 2$ & .076 \\
$\mathrm{X} 1 \mathrm{X} 3$ & .167 \\
\hline Sumber: data diolah, 2017 &
\end{tabular}

Pada Tabel 4 menunjukkan bahwa variabel independen dan variabel moderasi tidak ada yang signifikan. Hal tersebut ditunjukkan dengan koefisien probabilitas signifikansi yang lebih tinggi dibandingkan dengan signifikansi yang digunakan yakni sebesar 0,05. Jadi dapat disimpulkan bahwa tidak terjadi gejala heteroskedastisitas dalam model.

Tabel 5. mengindikasikan bahwa nilai durbin waston $(D W)$ sebesar 1,868 . Berdasarkan tabel DW dengan tingkat signfikansi sebesar 0,05 dan jumlah variabel sebanyak $5(\mathrm{k}=5)$ serta jumlah sampel sebanyak $125(\mathrm{n}=125)$ maka dapat diketahui nilai $d_{L}$ dan $d_{U}$. Nilai $d_{L}=1,6592$ serta $d_{U}=1,7574$ sehingga $4-d_{U}=4-1,7574=$ 
2,2426. Berdasarkan nilai $\mathrm{DW}=1,868>\left(\mathrm{d}_{\mathrm{U}}\right)=1,7574$ dan $<4-\mathrm{d}_{\mathrm{U}}=2,2426$, sehingga hal ini menunjukkan tidak terjadi autokorelasi atau bebas dari autokorelasi.

Tabel 5.

Hasil Uji Autokorelasi

\begin{tabular}{l}
\hline \multicolumn{1}{c}{ Durbin-Watson } \\
\hline a. Predictors: (Constant), X1X3, X1, X2, X3, X1X2 \\
\hline b. Dependent Variable: $\mathrm{Y}$ \\
Sumber: data diolah, 2017
\end{tabular}

Tabel 6.

Hasil Moderate Regression Analysis (MRA)

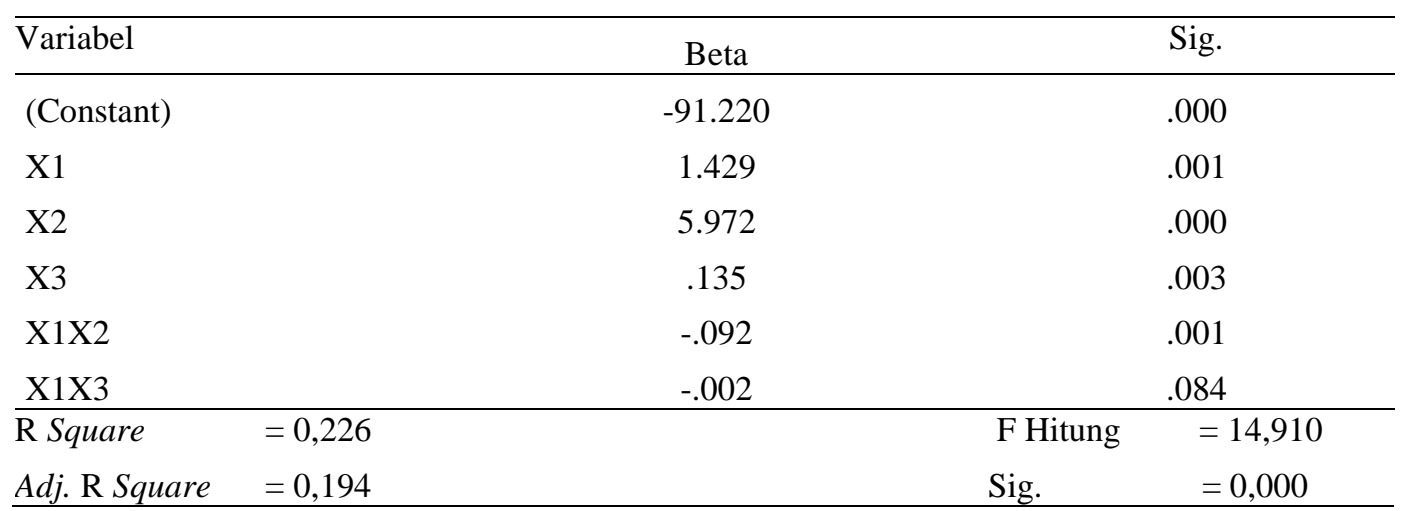

Sumber: Data diolah, 2017

Berdasarkan hasil pengolahan data yang terlihat pada Tabel 6 adapun persamaan regresi dalam penelitian ini adalah sebagai berikut.

$Y=-91,220+1,429 X 1+5,972 X 2+0,135 X 3-0,092 X 1 X 2-0,002 X 1 X 3+e$

Nilai konstanta sebesar -91,220 menunjukkan bahwa jika struktur modal, ukuran perusahaan, pertumbuhan penjualan dan interaksi struktur modal dengan ukuran perusahaan serta pertumbuhan penjualan dianggap konstan maka profitabilitas yang diperoleh akan mengalami penurunan sebesar 91,220 persen. Nilai koefisien regresi struktur modal (X1) sebesar 1,429 menyatakan bahwa setiap 
Ni Luh Made Wiwiek Oktapiani, Peran Ukuran Perusahaan ...

peningkatan satu persen struktur modal akan diikuti dengan peningkatkan profitabilitas sebesar 1,429 persen dan variabel lain dianggap konstan.

Koefisien regresi ukuran perusahaan (X2) sebesar 5,972 menyatakan bahwa peningkatan satu juta rupiah ukuran perusahaan akan diikuti dengan peningkatan profitabilitas sebesar 1,429 persen dengan asumsi bahwa variabel lain konstan atau tidak mengalami perubahan. Nilai koefisien regresi pertumbuhan penjualan (X3) sebesar 0,135 menyatakan bahwa setiap peningkatan satu persen pertumbuhan penjualan akan diikuti dengan peningkatan profitabilitas sebesar 0,135 persen dan variabel lain dianggap konstan.

Koefisien regresi interaksi struktur modal dengan ukuran perusahaan (X1X2) sebesar - 0,092 menyatakan bahwa setiap peningkatan interaksi antara struktur modal dengan ukuran perusahaan akan diikuti dengan penurunan profitabilitas sebesar 0,092 persen dan variabel lain dianggap konstan. Koefisien regresi interaksi struktur modal dengan pertumbuhan penjualan (X1X3) sebesar -0,002 menyatakan bahwa setiap peningkatan interaksi antara struktur modal dengan pertumbuhan penjualan menyebabkan terjadinya penurunan profitabilitas sebesar 0,002 persen dan variabel lain dianggap konstan.

Koefisien determinasi mengukur sejauh mana kemampuan model regresi menunjukkan variasi variabel terikat (Ghozali, 2012:97). Tabel6 menunjukkan nilai $\mathrm{R}^{2}$ sebesar 0,226 . Nilai tersebut mengindikasikan bahwa sebesar 22,6 persen profitabilitas dipengaruhi oleh struktur modal, ukuran perusahaan, pertumbuhan penjualan dan interaksi struktur modal dengan ukuran perusahaan serta 
pertumbuhan penjualan dan sisanya 77,4 persen profitabilitas dipengaruhi oleh variabel lainnya yang tidak dimasukkan dalam model regresi.

Uji F dilakukan untuk mengetahui secara bersama - sama pengaruh semua variabel bebas dan variabel moderasi terhadap variabel terikat yang dimasukkan dalam model regresi (Ghozali, 2012:98). Berdasarkan Tabel 6. Hasil uji F menunjukkan bahwa probabilitas signifikansi 0,000 lebih besar daripada $a=0,05$ berarti bahwa seluruh variabel bebas dan moderasi secara simultan berpengaruh signifikan terhadap profitabilitas.

Pengujian hipotesis secara parsial dilakukan dengan menggunakan uji t. Uji t pada dasarnya menunjukkan seberapa jauh pengaruh satu variabel bebas dan variabel moderasi secara parsial dalam menerangkan variasi variabel terikat (Gozhali, 2012:98).

Berdasarkan Tabel 6. diketahui bahwa nilai sig. struktur modal sebesar 0,001. Nilai sig. 0,001 $<a=0,05$ hal ini menunjukkan bahwa secara signifikan struktur modal berpengaruh terhadap profitabilitas. Koefisien regresi struktur modal (X1) sebesar 1,429 menunjukkan adanya pengaruh positif antara struktur modal terhadap profitabilitas. Hasil tersebut mengindikaskan bahwa hipotesis 1 yang menyatakan bahwa struktur modal berpengaruh negatif signifikan terhadap profitabilitas tidak sepenuhnya diterima. Dalam penelitian ini struktur modal memiliki pengaruh positif signifikan terhadap profitabilitas.

Hasil ini menunjukkan bahwa semakin tinggi tingkat struktur modal yang digunakan akan menyebabkan terjadinya peningkatan profitabilitas pada perusahaan sektor pertambangan yang terdaftar di Bursa Efek Indonesia. Hasil 
Ni Luh Made Wiwiek Oktapiani, Peran Ukuran Perusahaan ...

penelitian ini sesuai dengan trade off theory yang diungkapkan oleh Myers yang menyatakan bahwa perusahaan akan menggunakan utang sampai pada tingkat utang tertentu, dimana penghematan pajak (tax shields) dari tambahan utang sama dengan biaya kesulitan keuangan (financial distress) (Dewi dan Wirajaya, 2013). Hasil penelitian ini sesuai dengan penelitian yang dilakukan oleh Nawaz et al. (2011), Binangkit dan Raharjo (2014), Purba dan Yadnya (2015), Ali dan Agustin (2015) serta Sudaryo dan Pratiwi (2016) yang menemukan bahwa struktur modal berpengaruh positif signifikan terhadap profitabilitas.

Berdasarkan Tabel 6 diketahui bahwa nilai signifikansi interaksi ukuran perusahaan dengan struktur modal sebesar 0,001. Nilai sig. $0,001<a=0,05$ hal ini menunjukkan bahwa secara signifikan ukuran perusahaan mampu memoderasi pengaruh struktur modal terhadap profitabilitas. Hasil ini menunjukkan bahwa hipotesis 2 yang menyatakan bahwa ukuran perusahaan secara signifikan mampu memoderasi pengaruh struktur modal terhadap profitabilitas diterima. Nilai koefiisien regresi interaksi struktur modal dengan ukuran perusahaan (X1X2) sebesar -0,092 mengindikasikan bahwa ukuran perusahaan memperlemah pengaruh positif struktur modal terhadap profitabilitas.

Dengan adanya interaksi struktur modal dengan ukuran perusahaan menyebabkan pengaruh positif struktur modal semakin melemah. Hal tersebut disebabkan karena semakin meningkatnya ukuran perusahaan mengindikasikan total aset yang dimiliki perusahaan juga semakin meningkat, namun apabila aset tersebut semakin banyak dibiayai dengan menggunakan utang atau meningkatnya struktur modal menyebabkan aset tersebut menjadi tidak efektif. Semakin besar 
ukuran perusahaan mengindikasikan semakin banyak aset yang dibiayai dengan menggunakan utang menyebabkan semakin tinggi beban perusahaan untuk membayar beban utang sehingga penambahan aset perusahaan tidak efisien dalam meningkatkan profitabilitas karena terbebani utang perusahaan tersebut. Hasil penelitian ini sesuai dengan hasil penelitian yang dilakukan oleh Boutilda dan Gandakusuma (2014).

Berdasarkan Tabel 6 diketahui bahwa nilai signifikansi interaksi struktur modal dengan pertumbuhan penjualan (X1X3) sebesar 0,084. Nilai sig. 0,084 > a $=0,05$ menunjukkan bahwa secara signifikan pertumbuhan penjualan tidak mampu memoderasi pengaruh struktur modal terhadap profitabilitas. Hasil tersebut mengindikaskan bahwa hipotesis 3 yang menyatakan bahwa pertumbuhan penjualan secara signifikan mampu memoderasi pengaruh struktur modal terhadap profitabilitas ditolak. Putra dan Badjra (2015) menyatakan bahwa penjualan harus mampu menutupi biaya yang dikeluarkan untuk dapat meningkatkan profitabilitas. Apabila pertumbuhan penjualan yang terjadi diimbangi dengan penambahan biaya dan utang perusahaan maka pertumbuhan penjualan tidak berpengaruh terhadap profitabilitas. Berdasarkan hasil uji t tersebut menunjukkan bahwa pertumbuhan penjualan bukan merupakan variabel moderasi, sehingga pertumbuhan penjualan dapat digolongkan dalam variabel independen karena memiliki pengaruh langsung terhadap profitabilitas.

Berdasarkan Tabel 6 diketahui bahwa nilai signifikansi pertumbuhan penjualan $(X 3) 0,003<0,05$. Hasil tersebut menunjukkan bahwa secara signifikan pertumbuhan penjualan berpengaruh terhadap profitabilitas. Koefisien regresi 
Ni Luh Made Wiwiek Oktapiani, Peran Ukuran Perusahaan ...

pertumbuhan penjualan (X3) sebesar 0,135 menunjukkan bahwa pertumbuhan penjualan berpengaruh positif signifikan terhadap profitabilitas.

Berdasarkan hasil penelitian ini menunjukkan bahwa setiap terjadinya peningkatan pertumbuhan penjualan mengakibatkan profitabilitas perusahaan sektor pertambangan yang terdaftar di Bursa Efek Indonesia Periode 2012 - 2016 juga meningkat. Hasil penelitian ini sesuai dengan pernyataan oleh Husnan dan Pudjiastuti (2006:387) bahwa pertumbuhan penjualan berpengaruh terhadap profitabilitas perusahaan. Semakin tinggi tingkat penjualan bersih yang diperoleh perusahaan dapat mendorong semakin tingginya laba kotor yang mampu diraih, sehingga dapat mendorong semakin tingginya profitabilitas perusahaan. Hasil penelitian ini sesuai penelitian yang dilakukan oleh Sheikh and Wang (2013), Dramawan (2015), dan Farhana dkk. (2016).

Hasil penelitian ini menunjukkan bahwa struktur modal memiliki pengaruh posistif signifikan terhadap profitabilitas mengindikasikan implikasi bahwa pentingnya pihak manajemen perusahaan kedepannya untuk menentukan struktur modalnya agar penambahan utang yang digunakan perusahaan memiliki manfaat yang lebih tinggi daripada biaya kesulitan keuangan, sehingga hal ini dapat meningkatkan profitabilitas perusahaan. Interaksi antara struktur modal dengan ukuran perusahaan mampu memoderasi pengaruh struktur modal terhadap profitabilitas perusahaan mengindikasikan implikasi agar kedepannya pihak manajemen perusahaan lebih mengawasi penggunaan utang untuk pengelolaan aset perusahaan sehingga nantinya dapat memperkuat pengaruh positif interaksi antara 
struktur modal dengan ukuran perusahaan yang nantinya dapat meningkatkan profitabilitas perusahaan.

Hasil penelitian ini menunjukkan bahwa interaksi antara struktur modal dengan pertumbuhan penjualan tidak mampu memoderasi pengaruh struktur modal terhadap profitabilitas. Namun, sebagai variabel bebas pertumbuhan penjualan memiliki pengaruh positif terhadap profitabilitas. Hal ini mengindikasikan implikasi kedepannya pihak manajemen perusahaan memperhatikan pertumbuhan penjualannya agar dapat meningkatkan laba kotor perusahaan yang nantinya juga dapat meningkatkan profitabilitasnya.

\section{SIMPULAN DAN SARAN}

Simpulan penelitian ini adalah struktur modal berpengaruh positif signifikan terhadap profitabilitas dan ukuran perusahaan secara signifikan mampu memoderasi pengaruh struktur modal terhadap profitabilitas, namun pertumbuhan penjualan secara signifikan tidak mampu memoderasi pengaruh struktur modal terhadap profitabilitas perusahaan.

Saran yang dapat disampaikan yaitu bagi manajemen perusahaan hendaknya memperhatikan proporsi penggunaan utang agar tidak melampaui batas kemampuan perusahaan sehingga penghematan pajak atas utang dapat bermanfaat bagi perusahaan yang nantinya dapat meningkatkan profitabilitas perusahaan. Ketika penambahan aset yang diperoleh dari utang melampaui kemampuan perusahaan hal ini dapat menyebabkan terjadinya penurunan profitabilitas perusahaan, sehingga perusahaan perlu memperhatikan proporsi penggunaan utangnya dan memanfaatkan aset yang dimiliki sebaik mungkin. Manajemen 
Ni Luh Made Wiwiek Oktapiani, Peran Ukuran Perusahaan ...

perusahaan juga perlu memperhatikan pertumbuhan penjualan perusahaannya agar dapat meningkatkan profitabilitas yang diperoleh perusahaan karena pertumbuhan penjualan secara parsial memiliki pengaruh positif signifikan terhadap profitabilitas.

Saran lainnya yang dapat disampaikan kepada penelitian selanjutnya yakni hendaknya mempertimbangkan beberapa faktor - faktor lainnya yang mempengaruhi profitabilitas sebagai variabel dalam penelitiannya, selain itu peneliti selanjutnya hendaknya menggunakan perusahaan sektor lain di Bursa Efek Indonesia yang memiliki laporan keuangan lengkap. Hal ini dilakukan agar data yang digunakan pada penelitian ini dapat lebih valid. Hasil penelitian yang menunjukkan bahwa variabel pertumbuhan penjualan tidak cocok digunakan sebagai variabel moderasi pada penelitian ini hendaknya dapat menjadi saran bagi peneliti selanjutnya agar tidak menggunakan model penelitian yang serupa.

\section{REFERENSI}

Ali, Ahmad dan Sasi Agustin. 2015. Pengaruh Struktur Modal terhadap Profitabilitas pada Perusahaan Telekomunikasi. Jurnal Ilmu dan Riset Manajemen, 4 (9), 1-20.

Anwar, Muhadjir. 2009. Pengaruh Risiko Bisnis, Strategi Pertumbuhan, Struktur Modal terhadap Kinerja Perusahaan Makanan dan Minuman di Bursa Efek Jakarta. Jurnal Aplikasi Manajemen, 7 (2), 305-314.

Barus, Andreani Caroline dan Leliani. 2013. Anallisis Faktor - faktor yang Mempengaruhi Profitabilitas pada Perusahaan Manufaktur yang Terdaftar di Bursa Efek Indonesia. Jurnal Wira Ekonomi Mikroskil, 3 (2), 111-121.

Binangkit, A. Bagas dan Sugeng Raharjo. 2014. Pengaruh Struktur Modal Terhadap Kinerja Perusahaan dan Harga Saham pada Perusahaan Manufaktur di Bursa Efek Indonesia. Jurnal Aktual edisi Pebruari 2014, 1 (2), 28-34.

Boultida, Riris dan Iko Gandakusuma. 2014. Pengaruh Struktur Modal terhadap Profitabilitas Perusahaan: Studi Empiris Perusahaan - Perusahaan 
Manufaktur yang Terdaftar di Bursa Efek Indonesia Periode 2009 - 2013. Skripsi, Sarjana Departerman Manajemen Fakultas Ekonomi Universitas Indonesia Jakarta.

Chechet, Ishaya Luka and Abduljeleel Badmus Olayiwola. 2014. Capital Structure and Profitability of Nigerian Quoted Firms: The Agency Cost Theory Perspective. American Internationa Journal of Social Science, 3 (1), 139-158.

Dewi, Ayu Sri Mahatma dan Ary Wirajaya. 2013. Pengrauh Struktur Modal, Profitabilitas dan Ukuran Perusahaan pada Nilai Perusahaan. E-Jurnal Akuntansi Universitas Udayana, 4 (2), 58-372.

Dramawan, I Dewa Ketut Alit. 2015. Pengaruh Risiko Keuangan dan Pertumbuhan Penjualan pada Profitabilitas dan Nilai Perusahaan Property. Jurnal Buletin Studi Ekonomi, 20 (20), 158-167.

Fachrudin, Khaira Amalia. 2011. Analisis Pengaruh Struktur Modal, Ukuran Perusahaan, dan Agency Cost Terhadap Kinerja Perusahaan. Jurnal Akuntansi dan Keuangan, 13 (1), 37-46.

Farhana, Cintya Dewi; Gede Putu Agus Jana Susila; I Wayan Suwendra. 2016. Pengaruh Perputaran Persediaan dan Pertumbuhan Penjualan terhadap Profitabilitas pada PT Ambara Madya Sejati di Singaraja Tahun 2012 - 2014. E-Journal Bisma Universitas Pendidikan Ganesha Jurusan Manajemen, 4, 1-10.

Ghozali, Imam. 2012. Aplikasi Analisis Multivariate dengan Program IBM SPSS 20. Semarang: Badan Penerbit Universitas Diponegoro.

Halim, Abdul. 2015. Manajemen Keuangan Bisnis Konsep dan Aplikasinya. Jakarta: Mitra Wacana Media.

Hasan, Bokhtiar Md; A. F. M. Mainul Ahsan; Md. Afzalur Rahama; Md. Nurul Alam. 2014. Influence of Capital Structure on Firm Performance: Evidence from Bangladesh. International Journal of Business and Management, 9 (5), 184-194.

Husnan, Suad dan Enny Pudjiastuti. 2006. Dasar - dasar Manajemen Keuangan. Edisi Kelima. Yogyakarta: UPP STIM YKPN.

Khan, Fahad Najeeb; Ghulam Shabir Khan Niazi; Tayyaba Akram. 2013. Impact of Capital Structure on Firm Financial Performance: A Case Of The Pakistani Engineering Firms Listed On KSE. International Journal of Information, Business and Management, 5 (2), 218-240.

Kipesha, Erasmus Fabian and James Josephine Moshi. 2014. Capital Structure and Firm Performance: Evidences from Commercial Banks in Tanzania. Research Journal of Finance and Accounting, 5 (14), 169-178. 
Kumar, M Suman and Dr. P.Chitti Babu. 2016. Determinan of Capital Structure of Select Edible Oil Firms In India. Indian Journal of Commerce and Management Studies, 7 (1), 12-16.

Lim, Thian Cheng. 2012. Determinants of Capital Structure Empirical Evidence from Financial Services Listed Firms in China. International Journal of Economics and Finance, 4 (3), 191-203.

Marusya, Pontororing dan Mariam Magantar. 2016. Pengaruh Struktur Modal terhadap Profitabilitas pada Perusahaan Tobacco Manufacturers yang Terdaftar Di Bursa Efek Indonesia (BEI) Periode 2008 - 2015. Jurnal Berkala Ilmiah Efisiensi, 16 (03), 484-492.

Masfufah. 2016. Analisis Struktur Modal Terhadap Kinerja Keungan (Studi Kasus pada Perusahaan Farmasi yang Terdaftar di BEI Periode 2008 - 2014). Skripsi, Sarjana Jurusan Manajemen Fakultas Ekonomi dan Bisnis Universitas Hasanuddin Makasar.

Meidiyustiani, Rinny. 2016. Pengaruh Modal Kerja, Ukuran Perusahaan, Pertumbuhan Penjualan dan Likuiditas terhadap Profitabilitas pada Perusahaan Manufaktur Sektor Industri Barang Konsumsi yang Terdaftar di Bursa Efek Indonesia (BEI) Periode Tahun 2010 - 2014. Jurnal Akuntansi dan Keuangan FE Universitas Budi Luhur, 5 (2), 161- 179.

Mumtaz, Raheel; Shahnaz A. Rauf; Bashir Ahmed; Umara Noreen. 2013. Capital Structure and Financial Performance: Evidence from Pakistan (Kse 100 Index). Journal of Basic and Applied Scientific Research, 3 (4), 113-119.

Nawaz, Asad; Rizwan Ali; Muhammad Akram Naseem. 2011. Relationship between Capital Structure and Firms Performance: A Case of Textile Sector in Pakistan. Global Business and Management Research: An International Journal (2011), 3 (4), 270-275.

Niresh, J. Aloy. 2012. Capital Structure and Profitability in Srilankan. Global Journal of Management and Business Research, 12 (13), 83-90.

Nurcahayani, Rifna. 2014. Analisis Pengaruh Struktur Modal terhadap Profitabilitas (Studi pada Perusahaan Manufaktur yang Terdaftar di Bursa Efek Indonesia pada Tahun 2010-2012). Skripsi, Sarjana Fakultas Ekonomi dan Bisnis Universitas Diponogoro Semarang.

Pattweekongka, Supawadee and Kulkanya Napompech. 2014. Determinants of Capital Structure: Evidence From Thai Lodging Companies. International Journal of Arts \& Sciences, 07 (04), 45-52.

Pratheepkanth, Puwanenthiren. 2011. Capital Structure and Dinancial Performance: Evidence From Selected Business Companies In Colombia 
Stock Exchange Sri Lanka. International Refereed Research Journal, 2 (2), 171-183.

Purba, Ida Bagus Gde Indra Wedhana dan Putu Yadnya. 2015. Pengaruh Ukuran Perusahaan dan Leverage terhadap Profitability dan Pengungkapan Corporate Social Responsibility. E-Jurnal Manajemen Unud, 4 (8), 2428 -2443 .

Purwitasari, Elisa dan Aditya Septiani. 2013. Analisis Pengaruh Struktur Modal terhadap Profitabilitas (Studi Empiris pada Perusahaan Manufaktur yang Terdaftar di BEI Tahun 2009-2011). Diponogoro Journal of Accounting, $2(3), 1-11$.

Putra, Wela Yulia dan Ida Bagus Badjra. 2015. Pengaruh Leverage, Pertumbuhan Penjualan dan Ukuran Perusahaan terhadap Profitabilitas. E-Jurnal Manajemen Unud, 4 (8), 2052-2067.

Rostami, Jamshid Mohammadzadeh and Zohreh Akbarpour. 2012. Study of the Relationship between Capital Structure and Tax: Evidence from Iran. International Journal of Contemporary Business Studies, 3 (11), 35-45.

Rosyadah, Faizatur; Suhadak; Darminto. 2013. Pengaruh Struktur Modal terhadap Profitabilitas (Studi Pada Perusahaan Real Estate and Property Yang Terdaftar di Bursa Efek Indonesia (BEI) Periode 2009 - 2011). Jurnal Administrasi Bisnis, 3 (2), 1-11.

Rudangga, I Gusti Ngurah Gede dan Gede Merta Sudiarta. 2016. PengaruhUkuran Perusahaan, Leverage, dan Profitabilitas terhadap Nilai Perusahaan. E Jurnal Manajemen Unud, 5 (7), 4394-4422.

Sartono, Aggus. 2012. Manajemen Keuangan Teori dan Aplikasi. Yogyakarta: BPFE-Yogyakarta.

Shaputri, Silvia Juni dan Seto Sulaksono Adi Wibowo. 2016. Pengaruh Struktur Modal terhadap Kinerja Perusahaan Non Keuangan yang Terdaftar Di BEI. Jurnal Akuntansi, Ekonomi dan Manajemen Bisnis, 4 (2), 107-114.

Sheikh, Nadeem Ahmed and Zongjun Wang. 2013. The impact of capital structure on performance: An empirical study of non-financial listed firms in Pakistan. International Journal of Commerce and Management, 23 (4), 354-368.

Stein, Edith Theresa. 2012. Pengaruh Struktur Modal (Debt Equity Ratio) terhadap Profitabilitas (Return on Equity) (Studi Komparatif pada Perusahaan Industri Tekstil dan Garment yang Terdaftar di BEI Periode 2006-2010). Skripsi, Sarjana Jurusan Manajemen Fakultas Ekonomi dan Bisnis Universitas Hasanuddin Makasar. 
Sudaryo, Yoyo dan Ika Yanuar Pratiwi. 2016. Pengaruh Struktur Modal dan Likuiditas terhadap Profitabilitas dan Dampaknya terhadap Kinerja Keuangan (Studi Kasus pada Perusahaan Property, Real Estate and Building Construction yang Terdaftar Di BEI LQ45 Periode 2007-2014). Jurnal Indonesia Membangun, 15 (2), 1-20.

Sunarto dan Agus Prasetyo Budi. 2009. Pengaruh Leverage, Ukuran dan Pertumbuhan Perusahaan terhadap Profitabilitas. Telaah Manajemen Marlin, 6 (1), 86-103.

Thippayana, Pornpen. 2014. Determinants of Capital Structure in Thailand: School of Management, Walailak University, Thailand. Procedia - Social and Behavioral Sciences 143 (2014), 1074-1077.

Tjahjono, Rudi Setiadi. 2014. Faktor - faktor yang Mempengaruhi Kinerja Keuangan pada Perusahaan Manufaktur yang Terdaftar di Bursa Efek Indonesia. Jurnal Bisnis dan Akuntansi, 16 (1), 1-22.

Twairesh, Abdullah Ewayed M. 2014. The Impact of Capital Structure on Firm's Performance Evidence from Saudi Arabia. Journal of Applied Finance \& Banking, 4 (2), 183-193.

Umar, Husein. 2003. Business An Introduction. Jakarta: PT Gramedia Pustaka.

Wiagustini, Ni Luh Putu. 2014. Manajemen Keuangan. Denpasar: Udayana Universitas Press.

Yadav, Chette Srinivas. 2014. Determinants of the Capital Structure and Financial Leverage: Evidence of Selected Indian Companies. Asia Pacific Journal of Research, 1 (12), 121-130.

Yulia, Mona. 2013. Pengaruh Ukuran Perusahaan, Profitabilitas, Financial Leverage, dan Nilai Perusahaan terhadap Perataan Laba (Income Smoothing) pada Perusahaan Manufaktur, Keuangan dan Pertambangan yang Terdaftar di Bursa Efek Indonesia (BEI). Jurnal Akuntansi, 1 (2), 1 -24 . 